\title{
Bahan Ajar Keterampilan Membaca Berbasis Progress in International Reading Literacy Study untuk Siswa Kelas IV Sekolah Dasar
}

\author{
Khalida Hardani $^{1}$, Heri Suwignyo ${ }^{2}$, Nurchasanah ${ }^{2}$ \\ ${ }^{1}$ Pendidikan Dasar-Universitas Negeri Malang \\ ${ }^{2}$ Pendidikan Bahasa Indonesia-Universitas Negeri Malang
}

\begin{tabular}{l}
\hline \hline INFO ARTIKEL \\
\hline Riwayat Artikel: \\
Diterima: $30-08-2019$ \\
Disetujui: $18-06-2020$ \\
\hline Kata kunci: \\
reading skills; \\
Progress in International Reading \\
Literacy Studi (PIRLS); \\
keterampilan membaca;
\end{tabular}

Alamat Korespondensi:

Khalida Hardani

Pendidikan Dasar

Universitas Negeri Malang

Jalan Semarang 5 Malang

E-mail: hardanikhalida5@gmail.com

\begin{abstract}
ABSTRAK
Abstract: The research aims to produce Progress in International Reading Literacy Study-based teaching materials for class IV elementary school, in the form of student books and teacher instructions. This product is a companion learning book. The reading text that was developed was designed according to the age of class IV students using SMOG. The model used is Dick and Carrey. Research shows that (1) based on expert testing and the effectiveness of this teaching material is feasible to use, (2) there is an influence in the use of PIRLS-based teaching skills.

Abstrak: Penelitian ini bertujuan menghasilkan produk bahan ajar keterampilan membaca berbasis Progress in International Reading Literacy Study untuk kelas IV sekolah dasar yang berupa buku siswa dan petunjuk guru. produk ini merupakan buku pendamping pembelajaran. Teks bacaan yang dikembangkan dirancang sesuai dengan umur siswa kelas IV menggunakan Simplified Measure of Gobbledgook (SMOG). Model yang digunakan yaitu Dick and Carrey. Penelitian menunjukkan bahwa (1) berdasarkan uji ahli dan keefektifan bahan ajar ini layak untuk digunakan; (2) terdapat pengaruh dalam penggunaan bahan ajar keterampilan membaca berbasis Progress in International Reading Literacy Study.
\end{abstract}

Membaca merupakan kemampuan dasar yang perlu dimiliki semua orang. Keterampilan membaca diperoleh ketika siswa berada di sekolah. Salah satu keterampilan membaca yang diajarkan yaitu membaca pemahaman. Menurut Lee (2018) pentingnya mengembangkan membaca di kelas awal karena dapat membatasi sejauh mana keterampilan lain dapat mendukung pemahaman. Hal tersebut membuat keterampilan membaca menjadikan landasan penting untuk menempuh pendidikan yang lebih tinggi. Keterampilan membaca pemahaman sudah menjadi fokus secara internasional, salah satunya PIRLS (Progress in International Reading Literacy Study). Tes Progress in International Reading Literacy Study dilakukan oleh IEA (The International Association for Evaluation of Educational Achievement) setiap lima tahun yang dilakukan sejak tahun 2001 mengukur kemampuan membaca siswa kelas IV SD. Indonesia terakhir mengikuti tes pada tahun 2011 dengan skor 428 peringkat ke 42 dari 49 negara peserta lain. Menurut Basuki (2011) siswa kelas IV sekolah dasar hanya menguasai $30 \%$ bacaan sastra maupun informasi, hasil tersebut dilihat dari tes internasional dan tes lokal yang dilakukan.

Rendahnya tingkat keterampilan membaca disebabkan oleh beberapa alasan. Menurut Pratiwiningtyas (2017) pelaksanaan kegiatan membaca di sekolah dasar belum sesuai dengan tahapan membaca yang benar. Menurut Suryaman (2015) penyebab kemampuan membaca dan memecahkan soal yang lemah yaitu kecenderungan siswa menjawab pertanyaan pilihan ganda dengan menebak, butir-butir soal yang digunakan tidak disusun dengan sempurna atau kurang spesifik, teks yang digunakan kurang diperhatikan dari segi kualitas, di kelas belum mengutamakan pengembangan kompetensi membaca, kebiasaan membaca belum mencukupi, teori sastra yang diajarkan sering kurang tepat, serta kualitas butir soal belum sempurna sehingga jawaban dari guru dan siswa variasi. Terdapat pula tantangan yang perlu dilakukan untuk meningkatkan keterampilan membaca yaitu menentukan faktor kunci dalam lingkungan pembelajaran yang menjadi fokus siswa, menentukan sumber pembelajaran, dan menentukan batas-batas pembelajaran membaca (Croninger, 2009). Alasan yang dikemukakan oleh ketiga tersebut diperlukan bahan ajar yang dapat membantu siswa meningkatkan keterampilan membaca pemahaman.

Merancang bahan ajar keterampilan membaca yang baik harus sesuai dengan yang dibutuhkan oleh siswa. Hal tersebut sesuai dengan pendapat Syatriana (2013) materi pembelajaran atau buku sumber yang sesuai akan membantu siswa meningkatkan kemampuan bahasa mereka dan mememuhi tujuan kurikulum sekolah. Menurut Ortlieb (2016) dalam 
meningkatkan pemahaman siswa untuk teks kompleks dan struktur teks digunakan strategi secara eksplisit untuk membantu siswa memahami topik fiksi dan non fiksi. Selain itu, teks yang digunakan dalam bahan ajar perlu disesuaikan dengan umur atau kelas siswa. Menurut Yasa, dkk. (2013) keterbacaan berkaitan dengan keseluruhan unsur yang ada dalam teks atau materi bacaan. Salah satu tes mengukur tingkat keterbacaan yaitu SMOG (Simplified Measure of Gobbledgook). Dari kedua pendapat tersebut, bahan ajar membaca perlu digunakan dengan mengukur tingkat keterbacaan sesuai tingkatan agar tujuan dari standar isi dapat tercapai.

Sesuai dengan penelitian internasional, hasil observasi yang dilakukan di SDN Mulyorejo 2 Kota Malang menunjukkan keterampilan membaca pemahaman masih kurang. Hal tersebut sesuai dengan analisis kebutuhan yang disebarkan pada dua guru kelas IV dan tes keterampilan membaca untuk kelas IVA dan IVB. Tes yang diberikan untuk teks nonsastra (teks informasi) dengan judul "The Mystery of the Giant Tooth" dan teks sastra (teks cerita fiksi) dengan judul "Enemy Pie". Penilaian yang digunakan pada tes keterampilan sesuai dengan panduan penilaian Progress in International Reading Literacy Study. Hasil yang diperoleh dari tes keterampilan membaca tersebut, dapat disimpulkan keterampilan siswa untuk membaca teks sastra dan teks informasi masih di bawah rata-rata.

Penggunaan bahan ajar untuk mendukung keterampilan membaca siswa hanya dari buku pelajaran, buku LKS dan buku dari perpustakaan. Guru kurang mendukung siswa untuk mengasah keterampilan membaca dengan memberikan latihan soal. Hal itu dilihat dari angket yang diberikan, guru kelas IVA lebih sering memberikan soal tingkat rendah dan sedang dan guru kelas IVB lebih sering memberikan soal tingkat sedang dan tinggi. Oleh karena itu, diperlukan pengembangan bahan ajar yang dapat melatih dan meningkatkan keterampilan membaca siswa. Penelitian ini bertujuan untuk mengembangkan bahan ajar keterampilan membaca berbasis Progress in International Reading Literacy Study untuk siswa kelas IV sekolah dasar. Hal tersebut dipilih berdasarkan hasil studi pendahuluan yang dilakukan. Teks bahan ajar akan difokuskan sesuai dengan jenjang kelas menggunakan Simplified Measure of Gobbledgook dan pertanyaan-pertanyaan akan berbasis Progress in International Reading Literacy Study.

\section{METODE}

Penelitian pengembangan ini menggunakan Dick and Carrey yang terdiri dari sembilan tahapan langkah. Pemilihan model Dick and Carrey sesuai dengan awal pembuatan produk yaitu menganalisis kebutuhan siswa terlebih dahulu, dan model Dick and Carrey memliki langkah sistematis berdasarkan teori desain pembalajaran. Tujuan pengembangan produk menghasilkan bahan ajar keterampilan membaca berbasis Progress in International Reading Literacy Study yang valid, efektif, dan dapat digunakan sebagai pendamping pembelajaran.

Langkah pertama mengidentifikasi tujuan umum pembelajaran, dengan menganalisis buku siswa dan guru, obeservasi, memilih kompetensi inti dan kompetensi dasar. Hasil analisis pada buku siswa teks yang digunakan masih belum sesuai dengan jenjang umur, pertanyaan pada buku siswa belum mencakup tingkah rendah sampai sempurna, dan tidak ada jawaban dari pertanyaan buku siswa pada buku guru. Observasi dilakukan melalui angket analisis kebutuhan. Kompetensi inti yang digunakan yaitu pengetahuan dan keterampilan, sedangkan kompetensi dasar yang digunakan pada point 3.5 sampai 3.9, dan 4.1.

Langkah kedua melakukan analisis pembelajaran. Melakukan analisis materi pokok dan kegiatan pembelajaran yang akan dikembangkan. Analisis keterampilan membaca pemahaman dilakukan sesuai dengan tingkat pemahaman Progress in International Reading Literacy Study. Langkah ketiga analisis peserta didik dan konteks. Analisis dilakukan melalui pretest keterampilan membaca pemahaman. Keterampilan membaca yang diukur yaitu teks fiksi dan informasi. Analisis keterampilan membaca teks fiksi dan informasi dilakukan sesuai denga tujuan Progress in International Reading Literacy Study. Langkah keempat merumuskan tujuan khusus. Dilakukan perumusan tujuan khusus pembelajaran. Tujuan tersebut spesifik yang artinya dapat diamati dan diukur ketercapainnya. Tujuan yang dirumuskan meliputi sikap, pengetahuan, dan keterampilan.

Langkah kelima mengembangkan instrumen penilaian. Instrument yang digunakan yaitu penilaian sikap, pengetahuan, dan keterampilan. Penilaian pengetahuan berupa tes tulis pilihan ganda dan uraian. Penilaian sikap dilakukan saat siswa membaca dan mengerjakan buku siswa. Penilaian keteramoilan dilakukan saat siswa meringkas atau membuat cerita. Langkah keenam mengembangkan strategi pembelajaran. Pembelajaran ke $1-6$ memiliki enam kegiatan. Kegiatan tersebut, yaitu pendahuluan awal materi, membaca teks, melengkapi teks, latihan soal, dan meringkas atau membuat teks. Di akhir produk terdapat dua kegiatan evaluasi.

Langkah ketujuh mengembangkan dan memilih bahan pembelajaran. Kriteria yang digunakan dalam memilih materi/ bahan pembelajaran yaitu (1) kesesuaian materi dengan KI dan KD, (2) kesesuaian urutan materi pembelajaran dengan KI dan $\mathrm{KD}$, (3) tersedianya informasi yang dibutuhkan berupa narasi, (4) penyusunan materi disertakan dengan gambar yang sesuai, (5) tersedianya buku panduan guru mengenai materi yang ada dalam bahan ajar, (6) tersedianya instrumen peneliaian yang tepat digunakan dalam menilai siswa. Langkah delapan merancang dan melakukan evaluasi formatif. Evaluasi dilakukan melalui dua tahap. Tahap pertama yaitu evaluasi para ahli, yang terdiri ahli bahan ajar dan ahli materi bahasa. Tahap kedua yaitu evaluasi penggunaan bahan ajar pada siswa melalui tahap perorangan, kelompok kecil, dan uji coba lapangan. Langkah kesembilan melakukan revisi. Revisi produk pembelajaran dilakukan melalui empat tahap. Tahap tersebut diperoleh dari evaluasi formatif. Hasil dari evaluasi formatif dirangkum dan dilakukan revisi agar produk lebih baik/layak digunakan. 
Setelah melalukan sembilan langkah model Dick and Carrey, dilakukan uji coba produk. Uji coba produk dilakukan untuk mengumpulkan data dalam menunjang pengembangan bahan ajar keterampilan membaca berbasis Progress in International Reading Literacy Study. Uji coba produk dilakukan melalui lima bagian. Bagian pertama desain uji coba. Desain uji coba dilakukan dalam bentuk evaluasi formatif yang terdiri empat tahapan. Tahap pertama dilakukan validasi oleh para ahli bahan ajar dan materi. Hasil data dianalisis dan dilakukan revisi. Tahap kedua uji coba perorangan yang melibatkan tiga siswa dengan kemampuan berbeda. Tahap ketiga uji coba kelompok kecil yang melibatkan enam siswa dengan kemampuan berbeda. Tahap keempat uji coba lapangan yang melibatkan kelas IVA dan IVB.

Bagian kedua subjek coba. Subjek validasi ahli melibatkan satu dosen bahan ajar dan satu dosen ahli bahasa. Subjek lapangan melibatkan dua guru kelas IV SDN Mulyorejo 2 Malang, serta 34 siswa kelas IVA dan IVB. Bagian ketiga jenis data. Jenis data yang dihasilkan yaitu kualitatif dan kuantitatif. Data kualitatif berupa pernyataan yang berisi saran atau komentar dari para ahli materi dan media. Data kuantitatif berupa hasil penilaian yang diperoleh dari angket dan lembar observasi.

Bagian keempat instrumen pengumpulan data. Instrumen yang digunakan meliputi angket validasi, lembar penilaian, angket respons siswa dan guru. Angket validasi diberikan kepada ahli bahan ajar dan ahli bahasa. Aspek yang dinilai yaitu desain, bahasa, petunjuk guru, dan kelayakan isi. Lembar penilaian yang digunakan yaitu tes evaluasi, angket sikap, angket keterampilan. Angket respons siswa diberikan pada saat uji coba perorangan, kelompok kecil, dan lapangan. Aspek yang dinilai yaitu kemenarikan produk. Angket respons guru diberikan pada saat uji lapangan. Aspek yang dinilai yaitu kejelasan buku siswa dan buku petunjuk guru.

Bagian kelima teknik analisis data. Analisis hasil belajar penilaian sikap dan penilaian latihan soal menggunakan penilaian sesuai standar dari buku petunjuk guru keterampilan membaca berbasis Progress in International Reading Literacy Study. Hasil belajar penilaian pengetahuan dan keterampilan terlebih dahulu dilakukan uji prasyarat uji normalitas, uji homogenitas, dan uji hipotesis.

\section{HASIL}

Bahan ajar yang dikembangkan berupa buku pendamping siswa kelas IV SD semester II dan petunjuk panduan guru. Bahan ajar yang disusun hanya sebagai bahan ajar pendamping yang dapat digunakan untuk pembelajaran membaca. Bahan ajar disusun memperhatikan pemahaman membaca dari Progress in International Reading Literacy Study. Urutan pemahaman membaca yaitu rendah, sedang, tinggi, dan sempurna. Jumlah urutan pemahaman $20 \%$ untuk tingkat rendah, $30 \%$ untuk tingkat sedang, 30\% untuk tingkat tinggi, dan 20\% untuk tingkat sempurna. Teks yang digunakan berupa teks cerita sastra dan nonsastra. Teks yang digunakan diambil dari rujukan lain. Teks tersebut dimodifikasi sesuai dengan usia 9-10 tahun siswa kelas IV. Mengetahui teks sesuai dengan usia kelas IV menggunakan tes keterbacaan Simplified Measure of Gobbledgook. Berikut susunan yang dikembangkan dapat dilihat pada tabel 2. Bahan ajar ini terdiri dari tiga bagian, yaitu bagian awal, inti, dan akhir. Berikut susunan yang dikembangkan dapat dilihat pada tabel 3.

Tabel 2. Tingkatan Progress in International Reading Literacy Study

\begin{tabular}{|c|c|c|c|}
\hline Tingkat & Fokus & Indikator yang dikembangkan & Keterangan \\
\hline Rendah & $\begin{array}{l}\text { Mengambil informasi secara } \\
\text { eksplisit (terus terang) }\end{array}$ & $\begin{array}{l}\text { Mengidentifikasi informasi menentukan kalimat utama, serta } \\
\text { menyebutkan tokoh dan tempat. }\end{array}$ & \multirow{4}{*}{$\begin{array}{l}\text { Teks yang dikembangkan yaitu } \\
\text { teks eksplanasi ilmiah, teks } \\
\text { cerita diri/personal, teks } \\
\text { dongeng, teks laporan hasil } \\
\text { observasi, teks petualangan, dan } \\
\text { teks puisi. }\end{array}$} \\
\hline Sedang & $\begin{array}{l}\text { Membuat kesimpulan secara } \\
\text { langsung }\end{array}$ & $\begin{array}{l}\text { Menguaraikan bagian isi teks, mengurutkan peristiwa acak, } \\
\text { menentukan kata ganti dari kosakata, menyimpulkan bagian } \\
\text { kejadian yang terjadi dari teks, dan memberikan bukti } \\
\text { pendukung. }\end{array}$ & \\
\hline Tinggi & $\begin{array}{l}\text { Menginterpretasikan dan } \\
\text { mengintegrasikan gagasan } \\
\text { dan informasi }\end{array}$ & $\begin{array}{l}\text { Menunjukkan perisitiwa yang dialami tokoh, menjelaskan } \\
\text { perasaan tokoh dengan isi teks, menjelaskan makna kalimat, } \\
\text { membandingkan isi teks dengan judul, menilai tindakan yang } \\
\text { dilakukan dari teks, menjelaskan tindakan tokoh dari teks, } \\
\text { dan menjelaskan karakter tokoh. }\end{array}$ & \\
\hline Sempurna & $\begin{array}{l}\text { Mengevaluasi isi dan unsur } \\
\text { teks }\end{array}$ & $\begin{array}{l}\text { Menyampaikan pesan dari isi teks, menilai judul teks dengan } \\
\text { tema, dan menentukan sudut pandang penulis terhadap teks. }\end{array}$ & \\
\hline
\end{tabular}


Tabel 3. Sistematika Penyajian Buku Siswa

\begin{tabular}{ll}
\hline Awal & Sampul depan \\
\cline { 2 - 2 } Inti & Kata pengantar \\
\cline { 2 - 2 } & Daftar isi \\
Cara mengerjakan \\
Petunjuk mengenai cara membaca teks, mengerjakan latihan soal dan evaluasi
\end{tabular}

Bahan ajar juga dilengkapi dengan petunjuk penggunaan guru. Petunjuk guru terdiri atas tiga bagian utama, yaitu bagian awal, inti, dan akhir. Bagian awal terdiri atas kata pengantar dan daftar isi. Bagian inti terdiri atas pemetaan indikator, pengetahuan mengenai PIRLS, bagian-bagian buku dan penjelasan mengajar, serta penilaian pembelajaran membaca berupa sikap, dan hasil latihan soal serta evaluasi. Hasil latihan soal dan evaluasi menggunakan penilaian Progress in International Reading Literacy Study. Skor pilihan ganda menggunakan skor 1 untuk benar dan skor 0 untuk salah. Skor uraian menggunakan dua tipe. Tipe pertama menggunkan skor 1 untuk respons yang diterima dan skor 0 untuk respons yang tidak diterima. Tipe kedua skor 2 untuk pemahaman utuh, skor 1 untuk pemahaman tidak utuh, dan skor 0 tanpa pemahaman. Pada skor pemahaman utuh memberikan jawaban secara lengkap, sedangkan skor pemahaman tidak utuh memberikan jawaban singkat atau kurang lengkap. Bagian akhir terdiri atas daftar rujukan dan riwayat penulis.

Setelah pengembangan produk bahan ajar dilakukan tahap validasi ke para ahli bahan ajar dan materi bahasa. Aspek yang dihasilkan dari validasi berupa cover, bahasa, panduan guru, kemenarikan bahan ajar, dan kelayakan isi. Hasil penilaian validasi dari kedua ahli diperoleh pada tabel 4.

Tabel 4. Hasil Validasi Ahli Bahan Ajar dan Materi

\begin{tabular}{cccl}
\hline No & Subjek & Persentase Skor Perolehan & Kriteria Penilaian \\
\hline 1 & Ahli bahan ajar & $94,57 \%$ & Sangat valid \\
\hline 2 & Ahli materi & $75,89 \%$ & Cukup valid \\
\hline Skor rata-rata akhir & $85,23 \%$ & Sangat valid \\
\hline
\end{tabular}

Langkah berikutnya yaitu melakukan uji keefektifan. Uji keefektifan dilakukan pada saat uji coba. Uji coba pertama yaitu perorangan dengan melibatkan tiga siswa berkemampuan berbeda. Hasil uji coba perorangan menunjukkan rata-rata skor 88,5\%. Uji coba kedua yaitu kelompok kecil melibatkan enam siswa berkemampuan berbeda. Hasil uji coba kelompok kecil menunjukkan rata-rata skor $92,7 \%$. Uji coba ketiga yaitu uji lapangan yang melibatkan semua siswa kelas IVA dan IVB. Hasil belajar siswa dilihat dari uji normalitas, uji homogenitas, dan uji hipotesis. Keefektifan dinilai dari hasil belajar siswa, respons siswa dan guru. Hasil belajar siswa dilihat dari uji normalitas, uji homogenitas, dan uji hipotesis. Hasil uji normalitas kelas eksperimen posttest sastra dan nonsastra pengetahuan signifikasi sebesar 0,136 dan 0,165 yang menunjukkan bahwa data 
normal. Hasil uji normalitas kelas eksperimen posttest sastra dan nonsastra keterampilan signifikasi sebesar 0,095 dan 0,069 yang menunjukkan bahwa data normal. Pada hasil uji homogenitas kelas eksperimen posttest sastra dan nonsastra pengetahuan maupun keterampilan, nilai probabilitas signifaksi lebih dari 0,05 yang menunjukkan data homogeni. Uji hipotesis kelas eksperimen posttest sastra dan nonsastra pengetahuan signifikasi sebesar 0,000 dan 0,014 , sedangkan keterampilan sastra dan nonsastra signifikasi sebesar 0,017 dan 0,002. Kesimpulan dari uji hipotesis yaitu terdapat perbedaan antara pemberian bahan ajar keterampilan membaca berbasis Progress in International Reading Literacy Study pada kelas eksperimen dengan tidak memberikan bahan ajar pada kelas kontrol.

Perolehan skor respons guru sebesar 96,25\% yang menunjukkan hasil sangat layak. Perolehan skor respons siswa sebesar $86,17 \%$ yang menunjukkan hasil sangat layak. Kedua skor respons guru dan siswa memperoleh presentase yang dapat dikatakan bahwa produk bahan ajar keterampilan membaca berbasis Progress in International Reading Literacy Study layak untuk digunakan dalam pembelajaran.

\section{PEMBAHASAN}

Pengembangan produk yang dihasilkan yaitu bahan ajar keterampilan membaca berbasis Progress in International Reading Literacy Study untuk siswa kelas IV SD. Bahan ajar keterampilan membaca yang dikembangkan terdiri dari dua produk, yaitu buku siswa dan buku petunjuk guru. Petunjuk bahan ajar diberikan karena menurut Daryanto (2014) salah satu cakupan bahan ajar yaitu petunjuk belajar bagi siswa atau guru.

Bahan ajar keterampilan membaca dilakukan uji validasi dan uji keefektifan untuk mengetahui layak dan menarik bahan ajar untuk siswa kelas IV SD. Uji validasi yang dilakukan oleh ahli bahan ajar dan ahli materi terdapat beberapa saran yang harus direvisi sehingga memenuhi kriteria bahan ajar. Saran yang diberikan oleh valiadator yaitu (1) mengubah warna blok kata untuk memudah dibaca, (2) memperjelas bagian-bagian buku pada buku petunjuk guru, (3) memberikan penjelasan jumlah tingkat soal Progress in International Reading Literacy Study, dan (4) melengkapi langkah-langkah mengerjakan atau latihan berpikir sesuai tingkat Progress in International Reading Literacy Study. Keempat saran yang diberikan perlu diperhatikan untuk mengembangankan bahan ajar sesuai dengan pendapat Setiawan, dkk (2012) pengembangan bahan ajar perlu memperhatikan rancangan dari segi bentuk huruf, penyajian materi, dan kelengkapan panduan guru untuk memperjelas informasi yang diharapkan.

Uji keefektifan yang dilakukan oleh siswa melalui angket respons siswa terdapat beberapa catatan kesalahan penulisan yang sudah dibenarkan. Angket respons siswa diberikan untuk mengetahui kemenarikan dari produk. Uji keefektifan yang dilakukan oleh guru melalui angket respons guru terdapat saran yang perlu ditambahankan pada produk. Angket respons guru diberikan untuk mengetahui kejelasan dan kemudahan pada produk. Saran yang diberikan oleh guru yaitu menambahkan beberapa tujuan pembelajaran yang belum diberikan degree. Saran dari guru sudah direvisi dengan memberikan jumlah jawaban yang harus dicapai atau memberikan kata "benar". Hal ini sesuai dengan pendapat Dick (2009) terdapat tiga komponen utama dalam menyusun tujuan pembelajaran, salah satunya komponen ketiga yaitu menggambarkan kriteria untuk menilai perbuatan siswa dengan memberikan batas atau rentang. Menurut Smaldino, dkk (2011) degree merupakan persyaratan terakhir dari tujuan pembelajaran untuk mengisyaratkan standar atau kriteria menilai kinerja yang bisa diterima.

Pada bagian inti buku siswa terdapat kegiatan latihan melengkapi yang berisi kegiatan mencari tokoh dan tempat, diberikan permasalah dari teks, membandingkan ciri teks dengan bukti, mengevaluasi unsur puisi, mencari kata sulit (kosakata) dan gagasan pokok dan membuat peta konsep. Menurut Liebfreund (2016) kegiatan pemecahan pengetahuan kosakata berpengaruh pada pemahaman teks informasi siswa. Bermacam kegiatan dilakukan untuk membantu siswa lebih memahami isi bacaan. Hal tersebut sesuai dengan pendapat Abidin (2012) salah satu langkah perencanaan pembelajaran membaca yaitu menyusun kegiatan membaca dengan menentukan panduan membaca yang tepat dan strategi baca. Menurut Irawan (2017) upaya yang dapat meningkatkan keterampilan membaca siswa seperti menyediakan bahan ajar berbentuk buku teks yang akan memenuhi kebutuhan siswa, materi pembelajaran yang sesuai dengan membutuhkan pendekatan dan metode yang sesuai menentukan jalannya proses pembelajaran.

Penggunaan bahan ajar keterampilan membaca berbasis Progress in International Reading Literacy Study membantu siswa dalam memahami teks bacaan. Hasil evaluasi posttest yang diperoleh siswa kelas IVA mendapatkan persentase sebesar $58,8 \%$ untuk pengetahuan sastra, 52,6\% untuk pengetahuan nonsastra, 62,3\% untuk keterampilan sastra, dan $64,4 \%$ untuk keterampilan nonsastra. Siswa kelas IVB mendapatkan persentase sebesar $72,2 \%$ untuk pengetahuan sastra, $64,1 \%$ untuk pengetahuan nonsastra, 70,8\% untuk keterampilan sastra, dan 77,8\% untuk keterampilan nonsastra. Hal ini mengalami peroleh rentang skor jauh karena bahan ajar keterampilan membaca berbasis Progress in International Reading Literacy Study.

Perolehan kenaikan skor posttest kelas eksperimen (IVB) terjadi karena kegiatan yang dilakukan pada bagian inti buku siswa. Hal tersebut sesuai dengan pendapat Abidin (2018) pembelajaran membaca tidak hanya melibatkan siswa mampu membaca, tetapi juga melibatkan proses aktivitas mental dan kemampuan berpikir dalam memahami, mengkritisi, dan mereproduksi teks bacaan. Selain itu, menurut Saddhono (2014) aktivitas membaca pemahaman tidak hanya mengingat bacaan, tetapi juga mengarahkan pada menganalisis, menyintesis, mengevaluasi, dan mengaplikasikan. Dari kedua pendapat tersebut dapat disimpulkan pembelajaran membaca dapat berjalan dengan baik dengan mengarahkan pada aktivitas lebih tinggi yaitu menganalisis dan mengevaluasi teks bacaan selain mengingat bacaan. 


\section{SIMPULAN}

Hasil validasi oleh ahli bahan ajar dan materi menunjukkan bahan ajar keterampilan membaca berbasis Progress in International Reading Literacy Study valid dari segi cover, bahasa, kelayakan isi, kemenarikan,serta petunjuk guru. Hal ini dapat dilihat dari presentase total nilai dari para ahli. Uji coba dilakukan di SDN Mulyorejo 2 Kota Malang kelas IV menunjukkan bahan ajar keterampilan membaca berbasis PIRLS layak dari segi hasil belajar, respons siswa, dan respons guru. Berdasarkan hasil diatas dapat disimpulkan bahwa bahan ajar keterampilan membaca berbasis Progress in International Reading Literacy Study di kelas IV semester II ini valid dan layak digunakan dalam proses pembelajaran.

Untuk mengoptimalkan penggunaan bahan ajar keterampilan membaca berbasis Progress in International Reading Literacy Study, guru sebaiknya membaca langkah-langkah petunjuk penggunaan bahan ajar keterampilan membaca berbasis PIRLS sebelum melaksanakan pembelajaran bersama siswa. Produk bahan ajar keterampilan membaca berbasis Progress in International Reading Literacy Study dapat digunakan di kelas IV sekolah dasar lainnya. Untuk pengembangan produk lebih lanjut, teks dan latihan soal yang digunakan dapat lebih banyak dari yang dikembangkan.

\section{DAFTAR RUJUKAN}

Abidin, Y. (2012). Pembelajaran Membaca Berbasis Pendidikan Karakter. Bandung: PT Refika Aditama.

Abidi, Y., dkk. (2018). Pembelajaran Literasi Strategi Meningkatkan Kemapuan Literasi Matematika, Sains, Membaca, dan Menulis. Jakarta: Bumi Aksara.

Basuki, I. A. (2011). Kemampuan Membaca Pemahaman Siswa Kelas IV SD Berdasarkan Tes Internasional dan Tes Lokal. Jurnal Bahasa dan Seni, 39(2), 202-212.

Croninger, R. G., \& Valli, L. (2009). "Where Is the Action?" Challenges to Studying the Teaching of Reading in Elementary Classrooms. Educational Researcher, 38(2), 100-108. https://doi.org/10.3102/0013189X09333206

Daryanto., \& Dwicahyono, A. (2014). Pengembangan Perangkat Pembelajaran (Silabus, RPP, PHB, Bahan Ajar).Yogyakarta: Gava Media.

Dick, Walter, Lou Carey, James O. Carey. (2009). The Systematic Design of Instruction. In Educational Technology Research and Development. (Vol. 54). https://doi.org/10.1007/s11423-006-9606-0

Irawan, D. (2017). Developing Process Approach-Based Reading Textbook for Grade IV Students. Jurnal Prima Edukasi, 5(2), $139-150$.

Mullis, I. V. S., Martin, M. O., \& Sainsbury, M. (2015). Chapter 1: PIRLS 2016 Reading Framework. PIRLS 2016 Assessment Framework, 11-31.

Liebfreund, M. D., \& Conradi, K. (2016). Component Skills Affecting Elementary Students Informational Text Comprehension. Reading and Writing, 29(6), 1141-1160. https://doi.org/10.1007/s11145-016-9629-9

Lee, K., \& Chen, X. (2018). An Emergent Interaction between Reading Fluency and Vocabulary in the Prediction of Reading Comprehension among French Immersion Elementary Students. Reading and Writing. https://doi.org/10.1007/s11145018-9920-Z

Ortlieb, E. (2016). Looking Closer at Reading Comprehension Examining the Use of Effective Practices in a Literacy Clinic. English Teaching: Practice \& Critique, 15(2), 260-275. https://doi.org/10.1108/ETPC-08-2015-0069

Pratiwiningtyas, B. N, Susilaningsih, S., \& Sudana, I M. (2017). Pengembangan Instrumen Penilaian Kognitif untuk Mengukur Literasi Membaca. Journal of Education Research and Evaluation, 6(1), 1-9.

Saddhono, Kundharu \& St. Y. Slamet. (2014). Pembelajaran Keterampilan Berbahasa Indonesia Teori dan Aplikasi. Yogyakarta: Graha Ilmu.

Setiawan, D, dkk. (2012). Materi Pokok Pengembangan Bahan Ajar. Tangerang Selatan: Universtitas Terbuka.

Smaldino, Sharon E, dkk. (2011). Instructional Technology and Media for Learning: Teknologi Pembelajaran dan Media untuk Belajar. Jakarta: Kencana.

Suryaman, M. (2011). Analisis Hasil Belajar Peserta Didik dalam Literasi Membaca melalui Studi Internasional (PIRLS) 2011. Litera: Jurnal Penelitian Bahasa, Sastra, dan Pengajarannya, 14(1), 170-186. https://doi.org/10.21831/ltr.v14i1.4416

Syatriana, E., Husain, D., Jabu, B., \& Indonesia, M. (2013). A Model of Creating Instructional Materials Based on the School Curriculum for Indonesian Secondary Schools. Journal of Educational and Practice. 4(20), 10-19.

Yasa, K. N., Sutama M. \& Martha N. (2013). Kecermatan Formula Flesch, Fog Index , Grafik Fry , Smog, dan BI sebagai Penentu Keefektifan Teks Berbahasa Indonesia. Jurnal Program Pascasarjana Universitas Pendidikan Ganesha, 2(1). 